practically. This is, briefly, an intermediate home for old people butween the corporate and charity institutions and the private family. A suitable residence where all the comforts of rooms, surroundings, diet, seclusion, sympathetic personal care, and also medical attention when required, can be combined for a limited number of cases. Elderly people who from various causes are unable to command the quiet and seclusion of a home, and who would be better away from their former scenes, and have means to pay a moderate sum for this service, are to be found in almost every community. Old peoples' homes and other institutions bring them into a degree of prominence and subject to rules and regulations that are often irksome and unpleasant, such as the separation of a man and wife, and refusal to see friends except at stated times, and the imposing on them of certain perfunctory duties that break in on the cherished quiet and rest desired. Acting on my suggestion, a gentleman who has had several years' experience in the care of old people, has established a home of this character which will be opened January 1, at Ballston Springs, New York. Having made inquiries of the personal details of this work, I am sure it will be of interest to the profession and especially those who, like myself, have been advised concerning homes for old people, to give some of the facts.

Ballston Springs is a tree-embowered village in a valley five miles from Saratoga, and on the same mineral springs belt. Over fifty mineral springs of widely different values are located here. Invalids from all parts of the country live here for the sake of the waters which are free to all. The climate is very dry and bracing, being in the lower Adirondack snow belt, and mostly free from sleet storms and fogs. This town is nearly a hundred and fifty years old, and all the surroundings of good society and churches, with fine water supply and excellent drainage are exceptionally good. A large spacious residence near several springs is being fitted up for a small number of elderly people with the special object of furnishing a quiet congenial home, where personal interest and sympathy, with watchful care and attention are constantly at command. Medical supervision and nursing together with every other means, will be combined to make this a most delightful harbor for anchorage during the afternoon and sundown of life.

While I have no pecuniary interest in this home, I will answer with pleasure all inquiries relating to it, and give any information possible to any one who may be interested. T. D. Crothers, M.D.

\section{New and Important Pharmaceutic Product.}

New York, November, 1894.

To the Editor:-On July 28, last, we presented to the mem. bers of the medical profession through the columns of the Journal, a new brain and nerve tissue chemic food. The glycero-acid phosphate, the formula of which is almost identical with that of the lecithin of the brain cell and nerve tissue, $\mathrm{C}_{44} \mathrm{H}_{40} \mathrm{NPO}_{9}$; and which furnishes the proper chemic nerve cell and nerve tissue food to the vesicular neurine of the brain where nervous force is generated, and to the tubular or fibrous neurine which conducts it. In answer to numerous inquiries and requests for samples I have sent to all who requested it, a sample of this nerve food with the result that it is now in successful use in many of our hospitals with good clinical results.

For many years I have felt the necessity for a preparation of the hypophosphites, combined with iron, quinia and strychnia, which would not precipitate and which did not require to be kept in a cave or dark place during the warm months of the year. I desired a preparation which should be much richer in the hypophosphites than any I could obtain in the drug stores, and one which should also contain a more decided dose of iron, quinia and strychnia, to act as a stimulant tonic and reconstructive in all tuberculous, strumous and wasting diseases and during convalescence from grippe and other infectious complaints, and which would be a powerful therapeutic agent to stimulate the general nutrition by means of its action on the nervous system. This, I think from my own experience clinically, I have perfectly succeeded in doing, as the glycerid of the hy pophosphites comp. has a powerful stimulative action on the nutrition of all the organs, and this stimulant and tonic effect arises in a special stimulative action on the nervous system. It stimulates appetite and digestion, patients gain in weight and general appearance, and all report a feeling of invigoration from its use.

Each fluid ounce contains:

Hypophos. soda.

Hypophos. lime.

$\mathrm{Hy}$ pophos. potass.

Hy pophos. iron.

Hypophos. quinia, pure

Hypophos. strychnia.

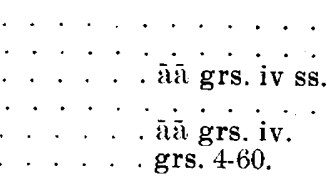

grs. $4-60$.

Dose from one to two teaspoonfuls in a wineglass of water before or with meals.

There is no possibility either of precipitation or of decom. position in this solution. It keeps indefinitely. A sample for physicians' use will be sent upon application to the author, at 305 West Eighty-sixth Street, near West End Avenue, New York. Very respectfully, E. C. Mans, M.D.

\section{ASSOCIATION NEWS.}

Photographs of Members.-Members of the Association are respectfully requested to send a recent photograph of themselves to the Journal. In so doing please write plainly the name and age of sender and date of photograph.

The Department of Public Health.-The following circular has been issued by Chairman Cochran :

Montgomery, Ala., Nov. 22, 1894.

Dear Doctor:-You are doubtless familiar with the effort which the American Medical Associarion is making to secure the enactment by the Congress of the United States of the bill now pending to create a Department and Secretary of Public Health. The great importance of the proposed legislation to the medical profession and to the people of the country is too evident to require argument. The only thing we need to discuss is how to secure for the bill the favorable consideration of the members of Congress. To this end this circular letter is addressed to the officers of State and other medical societies and associations with the urgent requést that such officers will promptly appeal to the members of their societies and associations to write to their members of Congress, in both Houses, requesting them to give their support and their votes in aid of the passage of the bill referred to. If all the doctors in all the States take part in a movement of this sort, and would keep it up for a few years, there can be no doubt that success would soon crown our efforts. Let no one consider his influence of little consequence, but let every one write promptly. Such a storm of letters would batter down all opposition.

Every one who receives a copy of this letter will please enter into correspondence with the Chairman of the Committee. Very respectfully,

(Signed.) Jerome Cochran, M.D., Chairman.

C. G. Comegys, M.D.,

N. S. Davis, M.D.

J. C. Culbertson, M.D.,

Ciras. Denison, M.D.,

U. O. B. WINGATE, M.D.

W. B. Atrinson, M.D.,

Liston H. Montgomery, M.D., Committee. 